Article

\title{
Densification and School Segregation: The Case of Oslo
}

\author{
Rebecca Cavicchia * and Roberta Cucca \\ Department of Urban and Regional Planning, Norwegian University of Life Sciences, 1430 Ås, Norway; \\ E-Mails: rebecca.cavicchia@nmbu.no (R.C.), roberta.cucca@nmbu.no (R.C.) \\ * Corresponding author
}

Submitted: 30 April 2020 | Accepted: 30 June 2020 | Published: 31 August 2020

\begin{abstract}
Urban densification has become a desirable development strategy in several cities. In addition to its environmental benefits, densification is also advocated as able to promote conditions for better coexistence and social mix. Studies have shed light on the likelihood of densification affecting residential patterns, but no attention has been paid so far to understanding the possible consequences on school segregation dynamics. As residential and school population composition are strongly intertwined, we argue that densification patterns may be associated with specific dynamics in school segregation. This study may thus pave the way to a better understanding of an understudied relationship. Using Oslo as a case study, we investigate how urban densification, here implemented through a neoliberal planning approach, can be associated with different forms of gentrification and new social divisions that are somewhat mirrored in the school segregation patterns of the city.
\end{abstract}

\section{Keywords}

Oslo; school segregation; socio-spatial inequalities; urban densification; urban planning

\section{Issue}

This article is part of the issue "Cities of Inclusion-Spaces of Justice" edited by Anja Nygren (University of Helsinki, Finland) and Florencia Quesada (University of Helsinki, Finland).

(C) 2020 by the authors; licensee Cogitatio (Lisbon, Portugal). This article is licensed under a Creative Commons Attribution 4.0 International License (CC BY).

\section{Introduction}

Urban densification has become a desirable urban development strategy in several cities. It has been identified as a solution to the environmental degradation deriving from urban sprawl since the 1990s. Indeed, the climate emergency has put considerable pressure on a shift in urbanisation towards a low-carbon city model (Rice, Cohen, Long, \& Jurjevich, 2020).

Densification has been gradually incorporated in climate policies at a European and global scale, as a desirable tool to deliver positive environmental, economic and social outcomes in contemporary cities (OECD, 2012; UN Habitat, 2014). In addition to its environmental benefits (Lim \& Kain, 2016), advocates for densification argue for its capacity to create socially diverse, mixed, and culturally vibrant urban areas (Ståhle, 2017). Evidence from various empirical studies suggests the opposite, however, as the densification of central areas may benefit only a well-off minority (Rérat, 2012). While studies have explored the likelihood of densification to affect residential patterns, no attention has been paid so far to understanding the possible consequences on school segregation dynamics, despite one of the greatest challenges for social cohesion today being the integration of migrant and vulnerable students in urban education systems. School segregation, the unequal distribution of children of different social and ethnic backgrounds across schools, is an important manifestation of these increasing divisions, and is itself a driver of new social inequalities. The fragmentation of social space tends to polarise access to education between more and less privileged groups, and between native and foreign populations (Bonal \& Belleï, 2018).

As residential and school population composition are strongly intertwined, we argue that there are several rea- 
sons to believe that densification patterns may be associated with the specific dynamics of school segregation. Especially in contexts where strict catchment areas are enforced, there is a strong relationship between school choice and residential choice. School segregation is an important spatial phenomenon. It affects, and is affected by, the area in which people live and how people move and travel. Urban densification, having an effect on residential patterns (Quastel, Moos, \& Lynch, 2012) and residential mobility dynamics (Wessel \& Lunke, 2019), thus has to be seen as playing a substantial role in affecting conditions for school segregation. Using Oslo, the capital of Norway, as a case study, we explore the role of densification in shaping residential patterns, and consequently in affecting school segregation.

Oslo is an interesting location for a study on this topic for numerous reasons. First, Oslo is a growing context, in terms of both economic and demographic trends, especially due to internal and international migration. To avoid urban sprawl, the city government has managed urban transformations by promoting urban densification strategies since the 1980s. Urban densification was intended to improve not only conditions of environmental sustainability, but also a more balanced socio-spatial structure in the city, promoting social mixing. Secondly, Oslo's local educational policy reflects the egalitarian socio-democratic welfare state regime, with traditionally low school competition (Imsen, Blossing, \& Moos, 2017). Thirdly, a (de facto) catchment area regulation on school admission is in place at primary and junior high school level (Haugen, 2020). These two school system characteristics mean that most of the observed differentiation between schools is consistent with the residential concentration of specific households in the catchment areas, rather than pedagogical differentiation.

In this article, we explore the following research question: How are the densification developments of the past two decades associated with changes in the distribution of children with different backgrounds in Oslo?

Using Oslo as a case study, we investigated how a neoliberal planning approach to densification, combined with a strict school catchment area geography, may increase the already strong social divisions of the school population. We draw on the literature on urban densification strategies and residential and school segregation, aiming to bridge the gap between these fields. This attempt is of particular relevance for two main reasons. First, it sheds light on the understudied relationship between urban planning strategies and school segregation. Second, it may have policy implications. As highlighted in North American studies, reducing school segregation, indeed, is estimated to significantly reduce economic costs for society or even diminish juvenile justice cases, and improve intergroup social cohesion (Mikulyuk \& Braddock, 2018).

The article proceeds as follows: In the next section, we present the state of the art of the academic debate on densification, residential segregation and school compo- sition; in the third section we present our research design and methods; in the fourth we introduce the case study; in the fifth we present the results of the investigation on densification and school segregation patterns; in the last section, we explore the relevance of urban planning strategies in shaping urban socio-spatial contexts differently affecting school segregation dynamics.

\section{Densification, Residential Patterns, and School Composition}

In this section, we explore the multifaceted relationship between densification, residential patterns, and school composition. We will first address densification, the narrative about its potential to create a socially mixed urban environment, and the challenges of turning such principles into practice. Then, we look at residential and school population composition, as potentially affected by densification, and as mutually influencing factors.

\subsection{Densification Strategies and Residential Patterns}

Claims about the advantages of dense urban environments in terms of social mix and urban diversity are not new. In the 1960s, Jane Jacobs advocated for a return to the traditional way of planning cities, through relatively high density and a mixture of functions (Jacobs, 1961). In her view, such an approach would make cities more diverse, vibrant and vital. These principles anticipated the compact city ideal and lead planning movements such as New Urbanism, Transit-Oriented and Smart Growth development (Sharifi, 2016).

With urban sprawl increasingly identified as a significant cause of socioeconomic and also ethnic spatial segregation (Ludlow, 2006), inner-city revitalisation through urban densification has been considered beneficial for improving greater social mix and cohesion (Power, 2001). It should be noted that there is no evidence that density per se delivers such outcomes (Bricocoli \& Cucca, 2016), but it is rather the variety of housing types and tenures (more likely to be found in dense than in sprawled areas) that is likely to play a more prominent role in creating the conditions for a lower level of segregation involving low income groups (Burton, 2000).

Densification is now increasingly recognised as a possible driver of socio-spatial inequalities and criticised for creating opportunities mainly for the most well-off (Rérat, 2012). This, in turn, may cause gentrification and the displacement of the most vulnerable, even when densification is pursued to combat socioeconomic segregation and to achieve a greater social mix (Lim \& Kain, 2016; Rosol, 2015). For instance, Rosol (2015) investigated Vancouver, where the combination of densification and social mixing policies has resulted in displacement and a lack of affordability, rather than greater social mixing.

These findings suggest that, if greater social mixing is the goal, densification strategies have to be comple- 
mented with a policy framework oriented at enhancing affordability and preventing displacement.

Scholars have investigated the possible implications of densification strategies on displacement and gentrification, in particular in the context of cities in the US (Quastel et al., 2012; Rice et al., 2020). As the pressure of climate change has increased and the low-carbon life-style' has become more popular, particularly among young middle-upper income earners (Rice et al., 2020), densification has also become a discursively powerful tool for improving city attractiveness. Spatial proximity and the creation of 'live-work-play' spaces (Quastel et al., 2012), have been actively used as branding tools in the advertisement of dwellings in densification hubs. We could find in such branding strategies and in the role of housing developers in pushing for the height, density and price of housing around the transport hubs, processes similar to those currently occurring in Oslo (Cavicchia, 2020). As the development of densification hubs results in high profitability for developers and high costs for residents, the resulting residential patterns may show an overrepresentation of middle-upper income households (Quastel et al., 2012).

The economic accessibility of densification hubs thus plays a fundamental role in shaping residential patterns. At the same time, household residential choice also affects residential patterns, and neighbourhood characteristics play an important role in this respect. As our investigation concerns the relationship between densification and school composition, we focus on the residential choices of family households, and the factors that may affect such choice in urban contexts.

So far, urban scholars have mainly focused on specific aspects connected with urban regeneration policies that may eventually lead to child-friendly cities, with gentrification implications (Lilius, 2014). Strategies oriented to better conditions of street safety, infrastructure for sport and culture, green spaces, school buildings, and backyards, are supposed to increase the attractiveness of neighbourhoods for families with school-age children. Critical urban scholars have highlighted that while childfriendly strategies may suggest a very positive attitude towards family needs, they may also be used as a proxy for 'middle-class friendly.' According to these studies, families are becoming the new catalysts for gentrification. Certain groups of dual-earner families in particular seem to find the city an attractive place to live, because of the proximity of amenities, a liberal climate for those who wish to depart from patriarchal ideals, and proximity to work, which makes it much easier to combine work and family life (Karsten, 2003). Middle-class nuclear families now seem to be important agents in gentrification processes.

So far, the literature on the link between childfriendly regeneration, gentrification and school segregation has mostly focused on US cities (Candipan, 2019). Very few studies have examined child-friendly urban renewal, gentrification and school choice in Europe, describing different patterns. As we will show in the next section, findings are mixed: In some cases, sociodemographic changes associated with gentrification have affected school composition, while in other contexts this has not been the case.

\subsection{Residential Patterns, School Choice and School Composition}

A large body of literature has demonstrated that residential patterns are crucial for understanding school segregation: Where children live determines, to a large extent where they go to school. In educational contexts characterised by a predominant public school system and strict school catchment areas, with one public school per district and very few private alternatives (Bernelius \& Vaattovaara, 2016), the large majority of pupils attend the school in their residential neighbourhood. In this case, school segregation is a clear reflection of residential patterns, but in contexts with a strong degree of choice, where parents can choose a school outside their residential neighbourhood, such as in Dutch cities (Boterman, 2019), the majority of pupils also attend a nearby school. This implies that while school policies on admission mediate the relationship between residential location and school segregation, geography matters in all contexts (Burgess, Wilson, \& Lupton, 2005). The importance of spatial proximity to schools implies that residential mobility behaviour is also often informed by considerations of school choice (Butler \& Hamnett, 2007). Moving to specific neighbourhoods to be close to the 'right' schools is common in many contexts, and is driven by class-based and raciallybased considerations of avoidance and peer-group seeking (Boterman, 2013). Cheshire and Sheppard (2004) have demonstrated that when school allocation policies are tied solely to residential address, schools can even have a direct effect on housing prices in the catchment areas around the most desired public schools: In other words, school choices are made through housing choices, and vice versa.

Scholars have researched the motivations behind residential mobility for households with school-age children in the Oslo context (Wessel \& Lunke, 2019). These studies have pointed out that choices are relatively strongly influenced by the socioeconomic status and educational background of parents, and middle-and upperclass families are most likely to actively select neighbourhoods that are considered privileged choices for families. Neighbourhood characteristics and the socioeconomic and ethnic composition of neighbourhoods have an impact on the residential decisions of households. These decisions, in turn, affect and reshape a neighbourhood's socioeconomic and ethnic composition (Lilius, 2014).

In contexts characterised by free school choice or a high availability of private school options, strategies that do not involve moving into the vicinity of a de- 
sired school include travelling greater distances from home to school. Butler and Hamnett (2007) have demonstrated that, in response to a mismatch between school and residential location, middle-class parents in London have adopted a metropolitan-wide strategy for (secondary) education. A second pattern, much less popular, is the middle-class 'colonisation' of local schools in diverse neighbourhoods. In the UK, this often implies the 'gentrification' of public working-class schools to create safety in numbers (Vowden, 2012), however, the relationship between urban planning strategies and school segregation and change dynamics remain largely unexplored.

Acknowledging that urban social and ethnic geographies tend to overlap (Huse, 2018), we attempt to explore how the residential patterns in densification areas are likely to be reflected in changes to the ethnic composition of the school population.

\section{Research Design, Data and Methods}

We primarily draw on the statistical analysis of quantitative data on school composition to investigate the multifaceted relationship between densification strategies and school segregation.

The statistical analysis focused on the evolution of school composition according to ethnic background (Arnesen, Mietola, \& Lahelma, 2007). Specifically, we focused on the analysis of data on the concentration of native/non-native speakers of the dominant language (Norwegian mother tongue/minority language mother tongue). There are two reasons for this choice: Language proficiency is a factor that parents prioritize when considering school options; and the typology of available data on school social composition in Oslo. Data on schools have been combined with data on densification patterns, supplied by the Agency of Planning and Building Service of Oslo Municipality, and mapped with the QGis application. We also relied on quantitative data on the ethnic composition of the population to discuss changing patterns of school composition in the light of changing residential patterns.

Additionally, we draw on the results of the qualitative analysis conducted by one of the authors as part of a research project on densification and socio-spatial inequalities in Oslo (Cavicchia, 2020). Such qualitative analysis includes interviews with planners, developers and politicians in the municipality of Oslo as well as an analysis of planning documents. We rely on that analysis to briefly reconstruct in this paper the motivations behind densification interventions and the attention given to goals of social mix/balance in the municipal plans. We were then able to discuss changes in the school composition and link such changes with specific approaches to densification. Additionally, we identified possible conflicts between the aims and actual outcomes of densification and potential shortcomings in the current policy framework for city development.

\section{Oslo: Socio-Spatial Dynamics, Local School System and Densification Strategies}

\subsection{Socio-Spatial Dynamics}

Urban socio-spatial segregation has traditionally been strong in Oslo, compared to many other European cities (Tammaru, Van Ham, Marcińczak, \& Musterd, 2015). Indeed, Oslo is considered a dual city, and the dynamics of social polarisation have long origins (Wessel, 2000). The Akerselva, the river that crosses Oslo in a north-south direction, has been considered the social and spatial division between the rich and resourceful West of the city and the poor East, since the 1800s (Wessel, 2000). Substantial East-West differences still exist. Single-family homes with gardens, urban parks, museums, and embassies characterise the West, where the upper classes live. The outer East is more characterised by highways, brownfield sites and block buildings, with many people with low-incomes and of non-Western ethnicity (Andersen \& Skrede, 2017).

Increasing levels of immigration have further strengthened the socio-spatial segregation patterns, as most immigrants have settled in the neighbourhoods where socioeconomic deprivation has been most visible. According to Turner and Wessel (2013), the importance of voluntary residential choice is not negligible in explaining the residential mobility of minority groups in the Oslo region. They found that some minority groups have remained loyal to the Eastern edge of the city, despite their success in climbing the social ladder.

Housing policies have also played a fundamental role in shaping segregation dynamics. Due to the neoliberal wave of the 1980s, Norway switched in a few years from a social homeownership housing model to a typically neoliberal housing system (Sandlie \& Gulbrandsen, 2017). The current Norwegian housing policy has been defined as poverty-oriented by Nordahl (2020) and its tools (housing allowance, municipal housing, and housing schemes) as likely to exacerbate the existing dynamics of polarisation. Indeed, studies demonstrate that recipients of housing subsidies and start-up loans from the State Housing Bank tend to settle in the most deprived districts of the city (Johannesen, Flatb $\varnothing$, Sellevold, \& Bohlin Borgersen, 2018). In 2016, more than 65\% of loans granted were used to buy a dwelling in the city's lowest-priced districts (Johannesen et al., 2018). The majority of the small proportion of municipal housing dwellings, often in highly segregated areas without decent housing standards, is also mainly in the inner and outer East area of the city. Although there has been a municipal effort in the past few years to increase the amount of municipal housing in the wealthier West, there is still a long way to go before there is an East-West balance.

Figure 1 clearly shows the patterns of ethnic divisions in Oslo. As of 2018, differences were very evident, especially in the outer city. The outer East, with the exception of $\emptyset$ stensj $\varnothing$, has the highest share of people with non- 


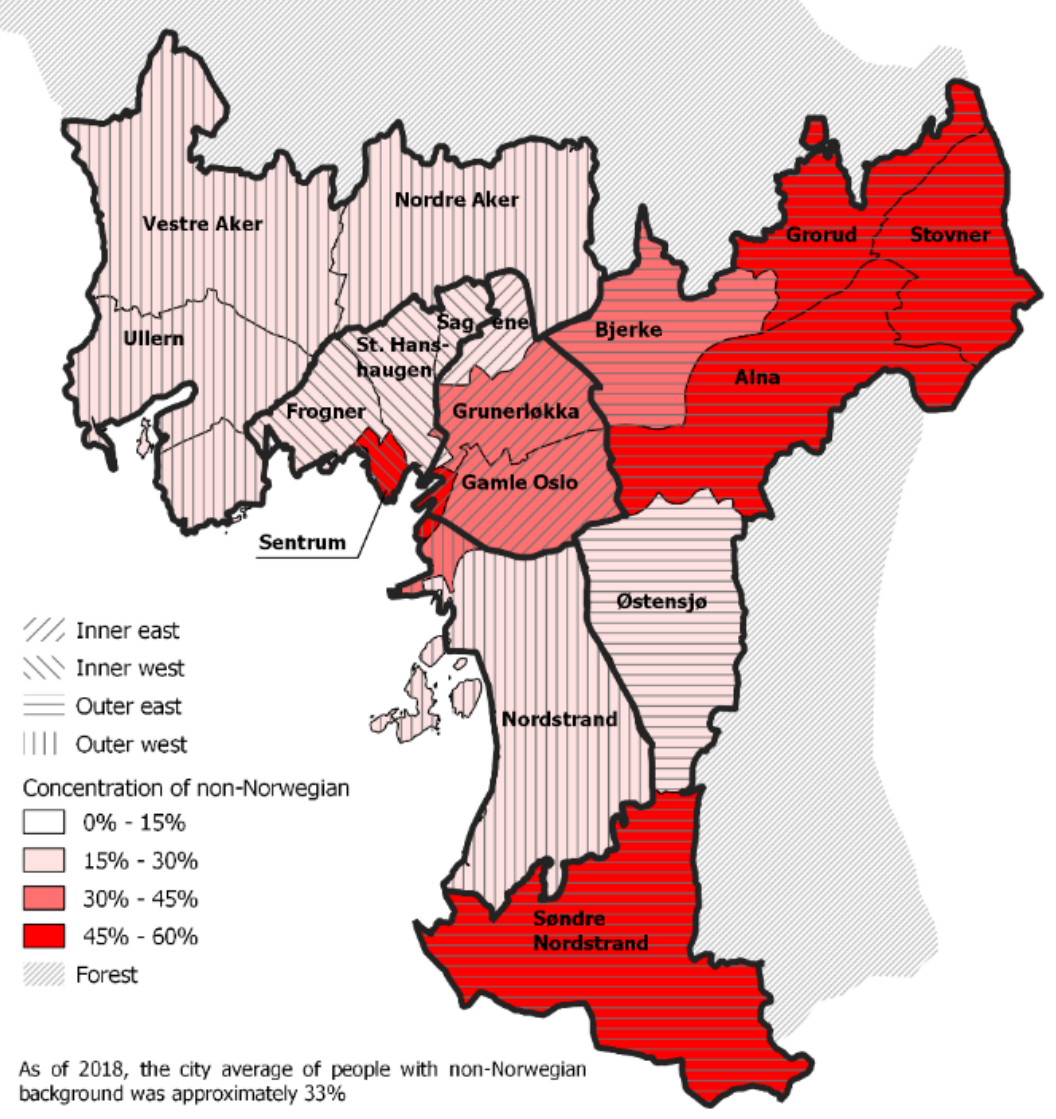

Figure 1. Residential ethnic composition in 2018. Source: Authors' elaboration on data provided by Oslo Statistikkbanken (2018a).

Norwegian ethnic background. By contrast, the districts in the West of the city show an on average lower concentration of people with non-Norwegian background, and also with respect to the city average.

Two issues emerging from the map need further explanation. First, the district of Nordstrand, despite being physically located on the East side of the city, counts as outer West (see Wessel, 2000). Secondly, the red area in the city centre mainly indicates a high concentration of ex-pats, often highly skilled temporary workers, employed in the banking, consulting, and IT industry.

Even though the ethnic divisions are sharp, the latest trends (2013-2018) show a somewhat decreasing EastWest polarisation compared to the previous period. The reason for this can be found in a more mixed situation in the inner city, where the historical inner East-inner West division has weakened compared to the past, and data for the periods 2008-2013 and 2013-2018 seems to confirm this trend. As we will show later, this is mainly related to gentrification dynamics and sociodemographic changes associated with densification interventions, which have been mainly implemented in the inner East and the fringe areas outside the inner East borders. We therefore do not measure the inner city according to the administrative borders, but extend it to include the newly developed densification hubs.

\subsection{Educational Policy and School Catchment Areas in Oslo}

The city of Oslo is divided into 115 primary school catchment areas. Students are mainly allocated to local schools according to their home address. Since 2004, families have had the right to choose a school outside their catchment area, but there is no guarantee of admission, as it depends on the available places in the receiving schools (Imsen et al., 2017). Currently 90 percent of primary school children attend school within their catchment area-although this percentage may vary in the city (Abildsnes, 2020), making Oslo an excellent location to study the effects of catchment area-based school policies and urban segregation (Hansen, 2017).

The role of public schools is strong in an international comparison, as the number of private schools is low (4.5 percent students in primary schools attend a private institution) and they are institutionally highly controlled. Schools are free, and most private schools are in part publicly funded $(85 \%$ by the State, $15 \%$ by families). As the vast majority of students attend their nearest public school, urban segregation has a direct effect on the composition of the schools, which is further reflected in the educational attainment of the schools (Hansen, 2017). 
Recent studies indicate that parents are also playing an increasing active role in school choice, in Oslo. As the pedagogy quality and orientation vary relatively little between schools (Haugen, 2020), school choice appears to be particularly linked to the school's social aspects. In particular, the results in the national test evaluation, and the percentage of minority language mother tongue students in the local school (information and data are available of the website of each public school in Norway) may be considered when choosing residential locations among school catchment areas (Wessel \& Lunke, 2019).

The literature also suggests that families consider other aspects when selecting residential location, such as neighbourhood quality and the availability of appropriate housing for growing household needs.

As argued in the next sections, densification strategies creating certain neighbourhood quality, characteristics and housing typologies, turn out to be relevant in shaping socio-spatial contexts that affect primary school segregation.

\subsection{Densification Strategies in Oslo}

Densification in Oslo is a primary tool in environmental and climate policies. During the 1980s, after a long period of suburbanisation and outward expansion, Oslo started to combat the detrimental effects of urban sprawl and to use densification as its main development strategy (Næss, Næss, \& Strand, 2011). Densification has mainly followed two strategies: densification from the inner to the outer city, and along public transport lines (Oslo Kommune, 2015b, 2018). Both strategies have been thought to guarantee efficient land use, while ensuring proximity to transport hubs and discouraging the use of cars (Hanssen \& Hofstad, 2013; Mete \& Xue, 2020). The municipal goal has been to create densification areas of high urban quality, with good networks and a functional mix (Oslo Kommune, 2018). In a recent study, Mouratidis (2018) provided evidence, by comparing compact and sprawled neighbourhoods in Oslo, about the likelihood of compact city characteristics having a positive effect on urban liveability. Proximity to public transport, to the most central areas, but also to services and leisure activities, which are typical elements of the newly densified areas, are emphasised as among the most influential aspects to positively affect neighbourhood satisfaction, and consequently liveability.

Geographically, densification has been disproportionally developed on the East side of the city, in particular in the districts of Grunerløkka, Gamle Oslo and Sagene. There are multiple reasons for this approach. First, Eastern Oslo is where industrial development mainly took place. The de-industrialisation process, started in the 1960s, left many brownfield areas and vacant spaces, which represented the most favourable ground for densification interventions. The West, instead, is characterised by more established residential communities, where resourceful inhabitants are powerful in protest- ing against the densification of their neighbourhoods. Their interests are also supported by a plan-the Small House Plan-which protects several single-family house areas from densification, many of which are located in the West (Andersen \& Skrede, 2017).

It should be noted that Oslo has limited expansion opportunities, due to both its topography and the protected forests around the city, so in addition to the mentioned power dynamics, city development has also experienced natural growth towards the East.

The outer city, instead, has been barely touched by densification interventions. The main motivations involve land-use efficiency and avoiding sprawl. However, economic reasons are also fundamental. Urban development in Oslo is largely in the hands of private developers, who also lead housing production. They built-and still build-where they can make the highest profit, in areas that are attractive, close to the city centre and to transport hubs, and where there is demand from people able to afford dwellings in such areas (interview with a developer in Cavicchia, 2020). This pro-growth approach, the neoliberal planning and housing systems in force, and other factors, have contributed to the creation of costly densification hubs (Cavicchia, 2020).

On this basis, it is evident that densification has played an important role in creating conditions for new spatial divisions and, consequently, new residential and school segregation dynamics. Balancing the living conditions between East and West Oslo and avoiding the reproduction of a more segregated city have been longstanding goals of the municipality (Figure 2). Attention to topics of social balance, social diversity and inclusion has become stronger in municipal plans across time. The plan approved in 2018 was the first elaborated under a red-green coalition, after around three decades of conservative administration, and the first explicitly mentioning the concept of social sustainability as a premise for housing development and better living conditions. Contextually, pro-growth arguments focusing on city attractiveness and competitiveness have also been recurring, as there is a vision of Oslo being a leading sustainable city nationally and internationally (Oslo Kommune, 2018).

Despite these goals, there are questions about the outcomes of densification strategies with respect to balancing living conditions of the city.

\section{Densification and School Composition}

In this section we describe recent patterns of school segregation in Oslo, taking into account the development of densification over the past twenty years. We explore such patterns in both the inner and the outer city and report our findings from the quantitative analysis.

The dataset we used involves primary schools and covers the period 2013-2018. Figure 3 shows patterns of school segregation in the 2018-2019 school year, and the areas affected by densification interventions in the 


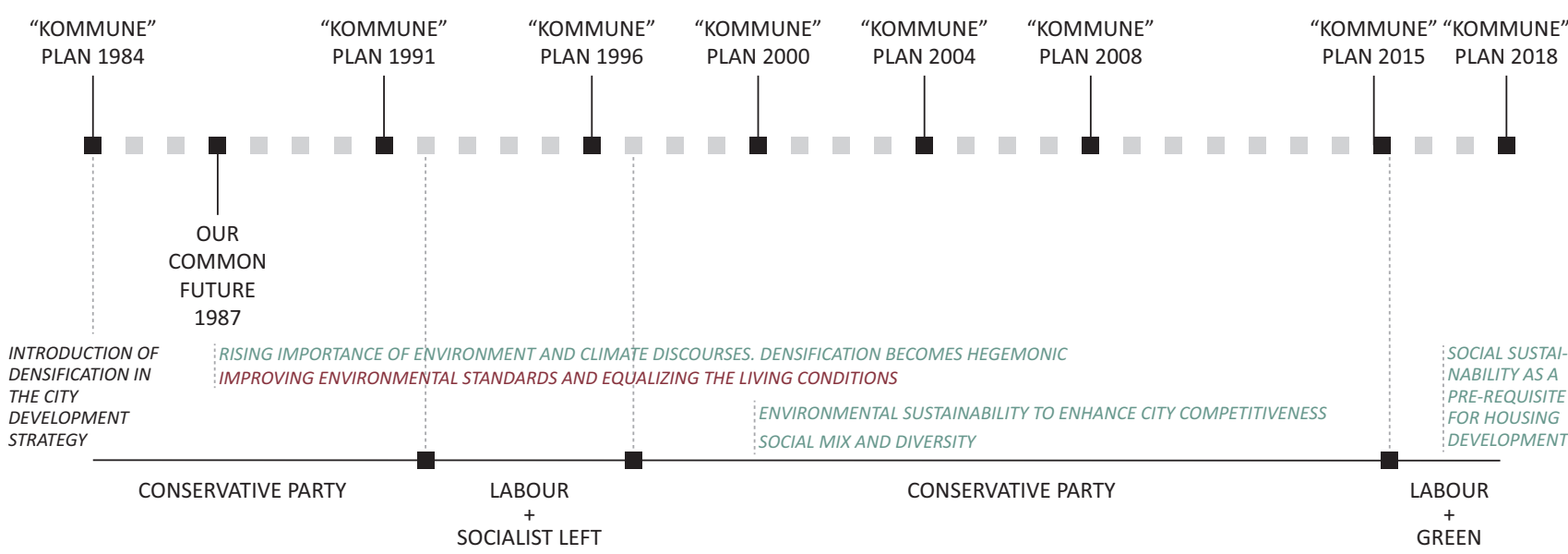

Figure 2. Municipal plans trajectory since the introduction of densification strategies. In red the wide longstanding city vision, in green emerging discourses. Source: Authors' elaboration based on the qualitative analysis of the municipal masterplans ('Kommune plan') of Oslo (Oslo Kommune, 1984, 1991, 2000, 2008, 2015b, 2018).

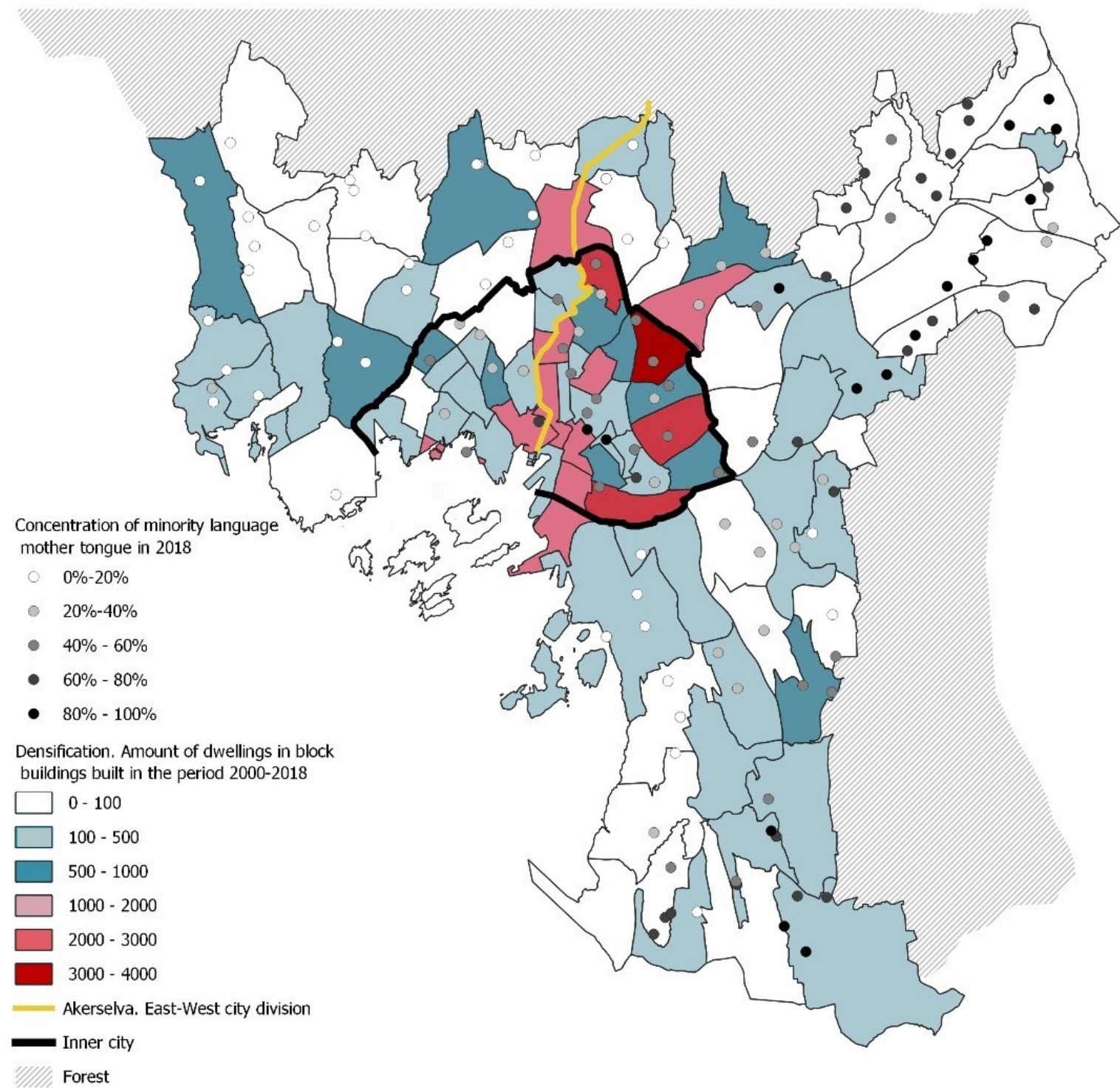

Figure 3. Densification and school ethnic composition. Source: Authors' elaboration on data provided by Oslo Statistikkbanken (2018c, 2018d). 
last 20 years. Despite the temporal limitation in the data concerning school dynamics, the elaboration shows interesting school segregation patterns that are worth discussing in relation to densification.

\subsection{Outer City: Low Densification and Consolidation of Traditional Patterns of School Segregation}

As mentioned, the outer city (both East and West) has been less touched by densification. We have already shown a strong East-West ethnic residential segregation, which is remarkably reflected in primary school segregation patterns (Figure 3). At the school level, however, these socio-demographic patterns are even more important, as schools often tend to be more segregated than neighbourhoods in Oslo. In the outer West, primary schools are marked by a strong concentration of dominant mother tongue children: 90 percent of the primary schools have more than 80 percent of pupils with a Norwegian background. This percentage is only 4 percent in the outer East, which demonstrates opposing segregation patterns. Looking at the average data for 2018, differences are again very evident. Almost 70 percent of children attending primary school have a minority language as mother tongue in the outer East, while this percentage drops to 10,6 percent in the outer West. Schools more than 90 percent of pupils with a minority language as mother tongue are mainly located in the outer East, particularly in the district of Stovner, the farthest Eastern area of the city. The peak in 2018, 99,3 percent of minority language mother tongue pupils, was reached in Vahl skole, in the district of Grønland in the inner East of the city, where only two pupils out of 269 were native Norwegian. By contrast, the school with the highest concentration of dominant mother tongue children, 97,8 percent, was Berg skole, in the district of Nordre Aker.

The East-West residential division is sharp, and school polarisation patterns even show an increase in the 2013-2018 timeframe, both in absolute terms as well as with respect to the city average (Table 1 ).

\subsection{Inner City: Medium-High Densification and the Risk} of School Colonisation

While there is a remarkable ethnic polarisation of the school population between the outer East and the outer West, the inner city shows a greater mix and a more even distribution of children with foreign backgrounds, as the figures in Table 2 show. As mentioned, many areas of the inner East score better than in the past on several socioeconomic indicators and the increase of people with a foreign background has somewhat dropped (comparing the periods 2008-2013 and 2013-2018). These are partly the results of the gentrification processes that have concerned some areas of the Grunerløkka district since the late twentieth century (Børrud, 2005). Nevertheless, we argue that also the urban densification of the inner East of the city, resulting in expensive residential areas, has played an important role in the mentioned social changes. As we will show next, we identified in the inner East of the city two main patterns of densification, which are associated with different school composition dynamics at local level.

The first pattern is related to the projects developed in the inner part of Grunnerløkka. Here the deindustrialisation that started in the 1960s has been a critical driver of gentrification. The industrial stock along the river Akerselva has been retrofitted and the workingclass neighbourhoods have become fertile ground for the dynamics of gentrification. In this part of the city, densification has thus followed previously activated gentrification processes. Densification has mainly happened here through demolition and reconstruction operations, as well as through large and small infill projects (see for instance the case of Rodeløkka, mentioned later). As noted by Hjorthol and Bjørnskau (2005), these operations have been part of the re-urbanisation of the inner core since the 1990s, accompanied by population growth, increasing housing prices, neighbourhood change and gentrification. Several publicly funded measures were also implemented in some of the areas in

Table 1. School segregation in Oslo. Concentration values and trends.

\begin{tabular}{lcccccc}
\hline & $\begin{array}{c}\text { Schools with } \\
\text { less than 20\% } \\
\text { of minority } \\
\text { language } \\
\text { mother tongue } \\
(2018)\end{array}$ & $\begin{array}{c}\text { Schools with } \\
\text { more than } 80 \% \\
\text { of minority } \\
\text { language } \\
\text { mother tongue }\end{array}$ & $\begin{array}{c}\text { Average } \% \\
\text { of minority } \\
\text { language } \\
\text { mother tongue }\end{array}$ & $\begin{array}{c}\text { Average } \% \text { of } \\
\text { mority language } \\
\text { mother tongue } \\
\text { (change 2013-2018 } \\
\text { with respect to } \\
\text { city average) }\end{array}$ & $\begin{array}{c}\text { Dissimilarity } \\
\text { index }\end{array}$ & $\begin{array}{c}\text { Dissimilarity } \\
\text { index } \\
\text { (change }\end{array}$ \\
\hline Inner East & $/$ & $10 \%$ & $(2018)$ & $-3,49 \%$ & 0,03 & $-0,004$ \\
Inner West & $/$ & $/$ & $44,5 \%$ & $-2,9 \%$ & 0,01 & $+0,0024$ \\
Outer East & $4 \%$ & $18 \%$ & $32 \%$ & $+1,8 \%$ & 0,23 & $+0,0128$ \\
Outer West & $90 \%$ & $/$ & $10,6 \%$ & $-1,11 \%$ & 0,17 & $-0,001$ \\
Oslo & $37,7 \%$ & $10,6 \%$ & $38,6 \%$ & $-1,73 \%$ & 0,5 & $+0,0113$ \\
\hline
\end{tabular}

Source: Authors' calculations on data provided by Oslo Statistikkbanken (2018a, 2018c). 
Table 2. School Composition and Densification Hubs in the Inner East.

\begin{tabular}{llccc}
\hline $\begin{array}{l}\text { Densification hubs in } \\
\text { the Inner East }\end{array}$ & $\begin{array}{l}\text { School catchment } \\
\text { area }\end{array}$ & $\begin{array}{c}\text { Average \% of minority } \\
\text { language mother } \\
\text { tongue (2018) }\end{array}$ & $\begin{array}{c}\text { Dissimilarity } \\
\text { index 2018 }\end{array}$ & $\begin{array}{c}\text { Average \% of minority } \\
\text { language mother tongue } \\
\text { (change 2013-2018) }\end{array}$ \\
\hline Nydalen & Fernanda skole & 49 & 0.0009 & - \\
Kvænerbyen & Vålerenga skole & 35,3 & 0,0007 & $-3,3$ \\
Lille Tøyen & Hasle skole & 24 & 0,0024 & -6 \\
Ensjø & Teglverket skole & 46,1 & 0,0011 & - \\
Løren and $\varnothing$ kern & Løren skole & 40,5 & 0,0002 & - \\
Løren & Sinsen skole & 57,6 & 0,0036 & $-3,7$ \\
& Refstad skole & 34,60 & 0,0008 & $-3,15$
\end{tabular}

Notes: Fernanda skole and Teglverket skole were opened after 2013, and Løren skole was closed in the period 2005-2014. It was thus not possible to reconstruct the changes in school composition for these schools. Refstad skole was the catchment area for the densification area in Løren, while Løren skole was closed. Source: Oslo Statistikkbanken (2018c).

the inner East of the city as a response to a territorial stigmatisation that marked them as immigrant ghettos (Huse, 2018). Such measures were oriented at making such areas more attractive for Norwegian people and legitimised, according to Huse (2018), an existing gentrification process. These and many other factors (i.e., market pressure, increasing land value, new transportation hubs) have contributed to the increase in housing prices in this part of the city (approximately 200\% in the period 2004-2018 (Oslo Statistikkbanken, 2018b). In particular, some areas of Grunerløkka have experienced great neighbourhood changes, with new cafes, trendy boutiques, newly decorated facades, and new contemporary buildings. Thanks to these aspects, Grunerløkka is today considered the coolest area of the city, particularly attractive for young people and hipsters. Here, the residential offer in terms of dwelling size, show a higher amount of one and two-room apartments compared to the city as a whole (Oslo Statistikkbanken, 2019). The gentrifiers have mainly been single people and couples, and families have met, and still meet, more challenges in finding housing solutions that match their needs in these areas. There are fewer multi-room dwellings compared to the outer city and parents may find bigger apartments too expensive to allow them to remain (Wessel \& Lunke, 2019).

These urban areas are in the Grunerløkka skole school catchment area. There were 45,5 percent nonNorwegians pupils in Grunerløkka skole in 2018. Unlike the schools in the new densification hubs (see Table 2), Grunerløkka skole shows a 4,5 percent increase in nonNorwegian pupils since 2013. We could not see a similar change in the residential patterns of the area. Using data on ethnic background for census tracts (Oslo Statistikkbanken, 2018a), we could roughly reconstruct the residential composition of the catchment area of Grunerløkka skole. We could see that the share of Norwegian and non-Norwegian residents (70\% and 30\% respectively) has remained almost stable in the considered time frame. Interestingly, if we focus on recent den- sification interventions, we can observe different patterns of change. For instance, in Rodeløkka (at the edge of the Grunerløkka skole catchment area), the biggest recent redevelopment area is located in the proximity of a chocolate industry-Freiaparken-and has been characterised by both new construction and the refurbishment of existing buildings. In 2013-2018 there was an approximate $5 \%$ increase in relative terms of native Norwegian speakers. Our hypothesis is that such residential patterns are not reflected in the school composition for two main reasons: (1) socio-demographic change has here concerned more singles and couples than families, (2) native young nest-leavers tend to settle in the inner city throughout their studies and early working career, but they typically move in the outer city when children arrive and approach school age (Wessel \& Nordvik, 2019). This happens in several compact areas of the inner city and shows that densification policies have been unsuccessful in the creation of stable inner-city communities. We thus argue that the neighbourhood demographic change introduced by this pattern of densification has not so far fostered significant changes in school composition.

A different pattern characterises the newly developed densification areas. Going out from the core of Grunerløkka, it is in the areas of Nydalen, Løren, Hasle, $\emptyset$ kern, Ensjø and Kvænerbyen, that densification has produced the major residential developments. Here, former industrial areas started to be transformed into new residential areas at the beginning of 2000, and neighbourhoods have been built from scratch, with new dwellings, infrastructure, public spaces and facilities. "From industrial areas to liveable urban hubs" has been the vision for these areas (Oslo Kommune, 2015a). Proximity to transport hubs, as well as their vicinity to the inner core, make them attractive and also expensive places to live. Indeed, land prices around transport hubs have skyrocketed and developers, the main housing providers in Oslo, can extract huge value from developing new real estate there. The combination of a deregulated housing market with the poor implementation of housing affordability tools, 
also makes housing accessibility in the densification hubs rather low (Cavicchia, 2020).

Some of the newly densified areas, such as Løren and Hasle in the district of Grunerløkka, are evidently targeted at families (interview with a developer in Cavicchia, 2020). For instance, in Løren the offer of multi-room flats, car-free areas, playgrounds in the green areas and schools with good reputations make the area particularly attractive for families with children (Selvaag Bolig, OsloMet, \& Rodeo, 2019). Compared to the rest of Grunerløkka, Løren's inhabitants have higher incomes on average, including among those with immigrant backgrounds, and a higher share of home-owners (Selvaag Bolig et al., 2019). There seem to be similar patterns, even though less evident than in Løren, in the new development areas of Kvænerbyen and Ensjø in the Gamle Oslo district and Nydalen in the Sagene district. Data shows that, compared to the subdistricts of the inner East where new densification hubs are not present, the subdistricts where major densification interventions have been developed: (1) score better on income and education level, (2) have lower shares of people with foreign ethnic background, and (3) have more housing options for families in terms of dwelling size.

There is a considerably more balanced distribution of pupils observable in these areas compared to the schools in the outer city. Indeed, none of these schools (Fernanda, Vålerenga, Teglverket, Løren, Sinsen, Refstad and Hasle skole) show remarkably strong segregation patterns. The proportion of pupils with a minority language as their mother tongue varies here between approximately 35 percent and 60 percent (the only exception is Hasle skole with 24 percent). However, we also observed a decrease in non-Norwegian pupils in the 2013-2018 period (Hasle skole is again the most evident case among those examined, with a decrease of 6 percent). Such decreases, indeed, may indicate that a sort of 'Norwegian-pupils colonisation' is in the making, and we expect that the patterns found will continue or even increase in the years to come.

\section{Final Remarks}

In this article, we argue that urban planning strategies may play an important role in shaping socio-spatial contexts that affect school segregation. While the literature developed so far has focused on urban renewal strategies and their possible impacts in terms of gentrification and changing school segregation dynamics in contemporary cities, this article has focused on the implications of urban densification. Densification has been introduced in many cities as a strategy to limit urban sprawl, however, compact cities are also believed to promote conditions for better coexistence and social mix (OECD, 2012). Indeed, in our case study, the city of Oslo, densification has been supposed to contribute to a better social balance between more deprived and privileged neighbourhoods, formally the East and the West of the city. We have explored whether densification strategies in Oslo are associated with changes in the distributions of students with a different ethnic background in primary school. The main results of this investigation highlight some possible policy implications.

First, it is crucial to focus on how densification has been implemented. We have explained that densification in Oslo was developed following neoliberal principles in both planning processes and housing policies. The provision of affordable housing has been extremely limited, with private developers essentially being the only housing providers (Cavicchia, 2020). Additionally, following market dynamics, densification strategies have created certain neighbourhood quality, characteristics and housing typologies (more or less oriented to families with school age-children), turning out to be relevant in shaping socio-spatial contexts that affect primary school segregation.

Second, it is relevant to focus on where densification has mainly been implemented, and where it has not been implemented. According to both private market interests and urban sustainability criteria, densification in Oslo has mainly been developed in the inner city. In the outer city, where residential and school segregation patterns are remarkably high, we mainly observed mild densification interventions. The lack of significant urban transformation in both the outer East and West, together with the lack of strong measures for housing affordability, play a role in the consolidation of the existing East-West polarisation patterns. In the inner city, the situation is more nuanced and this approach to densification shows two main resulting patterns of school composition dynamics.

In some areas of the city, densification can be associated with family-gentrification dynamics in the housing market and the potential 'Norwegian-pupils colonisation' of primary schools. This seems to be the case in the examined brand-new and expensive compact neighbourhoods, realised in previously low-medium status districts of the inner East of Oslo. Here, indeed, while the current situation shows a higher social mix compared to other areas in both the inner and the outer city, the described changes in socio-ethnic indicators show a shift towards increasingly homogeneous urban areas (Hill, 2012) and a risk of neighbourhood segregation, as in Løren (Selvaag Bolig et al., 2019). A second pattern of densification is consistent with more traditional gentrification dynamics and mainly concerns established compact areas in the inner city (Grunerløkka mentioned above). In this case, densification has taken place as part of the inner-city revitalisation, which occurred because of the city's deindustrialisation. The main aspects of the inner-city revitalisation have involved building upgrades due to the influx of better-off households, infill projects, increased residential attractiveness and artistic. These areas have become the preferred residential destinations of young adults, couples and hipsters, the so-called creative class, young gentrifiers attracted by the urban lifestyle. Consequently, 
the neighbourhood demographic trends introduced by this densification pattern has not fostered significant changes in the social profiles of families with school-age children, and, thus, in the composition of schools. The residential stability of families with school-age children still appears to be quite low (Wessel \& Nordvik, 2019).

This analysis highlights two main problems. Environmental, climate and transportation policies, together with substantial economic advantages, require densification in the inner city, fostering the greatest land-use efficiency possible. Densifying in the outer city would, indeed, goes against both environmental principles and the willingness of developers to build new residential areas (Cavicchia, 2020). However, existing segregation patterns would suggest the necessity of more affordable housing in the outer West, through densification interventions characterised by housing accessibility criteria. In the West, social balance in school composition is a long way off. Nevertheless, even where social balance seems to be a closer goal, as in the new inner-city densification areas, the lack of affordable housing is affecting a shift towards higher segregation, instead of a greater mix, both in residential and in school patterns.

As previously argued in the gentrification and social mix literature (Bridge \& Butler, 2011), when it comes to school segregation dynamics, a strategy to break the segregation of privileged groups is also missing. In Oslo, while densification may also potentially be a tool to achieve higher social balance in school composition, the neoliberal approach, the lack of affordable housing, and of measures to prevent displacement risk, means that it reproduces existing inequalities and produces new social divisions. The coexistence of residential and school segregation, as well as possible new forms of gentrification, challenge the rhetoric of urban densification as a sustainable way of developing Oslo.

In summary, our analysis suggests that planning strategies may have a significant impact on school segregation dynamics in cities characterised by a predominance of the public school and strict catchment area systems, however, planning strategies and local education policies have not usually been integrated. In the case of Oslo, decision-makers should be more aware of the potential consequences of densification strategies for school choice practices, taking into consideration aspects related to the socio-demographic profile and trends in the existing and newly developed areas, as well as school segregation dynamics. Better integration in the policy domains of education, planning, and housing is needed to limit a further increase in school segregation processes. Investigations indeed show that it is only when such a cross-sectoral perspective is adopted that the successful governance of school segregation can be achieved.

\section{Acknowledgments}

We would like to thank the three anonymous referees and $\varnothing$ yvind Bjerkestrand and Petter Næss for their use- ful remarks and suggestions. This research was carried out under the projects ECASS-European Cities Against School Segregation (Erasmus+Strategic PartnershipHorizon 2020, 2019-2022) and 'Densification and SocioSpatial Inequalities: The Case of Oslo' supported by the Norwegian University of Life Sciences.

\section{Conflict of Interests}

The author declares no conflict of interests.

\section{References}

Abildsnes, M. (2020). Oslo speilet (Er noen barneskoler i Oslo mer foretrukket enn andre?) [The Oslo mirror (Are some primary schools in Oslo more preferred than others?)]. Oslo: Oslo Kommune.

Andersen, B., \& Skrede, J. (2017). Planning for a sustainable Oslo: The challenge of turning urban theory into practice. Local Environment, 22(5), 581-594.

Arnesen, A. L., Mietola, R., \& Lahelma, E. (2007). Language of inclusion and diversity: Policy discourses and social practices in Finnish and Norwegian schools. International Journal of Inclusive Education, 11(1), 97-110.

Bernelius, V., \& Vaattovaara, M. (2016). Choice and segregation in the 'most egalitarian' schools: Cumulative decline in urban schools and neighbourhoods of Helsinki, Finland. Urban Studies, 53(15), 3155-3171.

Bonal, X., \& Belleï, C. (2018). Understanding school segregation: Patterns, causes and consequences of spatial inequalities in education. London: Bloomsbury.

Boterman, W. (2019). The role of geography in school segregation in the free parental choice context of Dutch cities. Urban Studies, 56(15), 3074-3094.

Boterman, W. R. (2013). Dealing with diversity: Middleclass family households and the issue of 'black' and 'white' schools in Amsterdam. Urban Studies, 50(6), 1130-1147.

Bricocoli, M., \& Cucca, R. (2016). Social mix and housing policy: Local effects of a misleading rhetoric. The case of Milan. Urban Studies, 53(1), 77-91.

Bridge, G., \& Butler, T. (2011). Mixed communities: Gentrification by stealth? Bristol: Policy Press.

Burgess, S., Wilson, D., \& Lupton, R. (2005). Parallel lives? Ethnic segregation in schools and neighbourhoods. Urban Studies, 42(7), 1027-1056.

Burton, E. (2000). The compact city: Just or just compact? A preliminary analysis. Urban Studies, 37(11), 1969-2006.

Butler, T., \& Hamnett, C. (2007). The geography of education: Introduction. Urban Studies, 44, 1161-1174.

Børrud, E. (2005). Hva skjer på Grünerløkka? Raske endinger og stabilisernde transformasjon [What happens at Grünerløkka? Rapid changes and stabilizing transformation]. In J. Aspen (Ed.), By og byliv $i$ endring: Studier av byrom og handlingsrom i Oslo [City and urban life in change: Studies of urban space and 
action space in Oslo] (pp. 273-309). Oslo: Scandinavian Academic Press.

Candipan, J. (2019). Neighbourhood change and the neighbourhood-school gap. Urban Studies, 56(15), 3308-3333.

Cavicchia, R. (2020). Densification and housing accessibility. Is Oslo a city with room for everyone? Paper presented at the IV Convegno SISEC, Turin.

Cheshire, P., \& Sheppard, S. (2004). Capitalising the value of free schools: The impact of supply characteristics and uncertainty. The Economic Journal, 114(499), F397-F424.

Hansen, M. N. (2017). Segregering og ulikhet i Osloskolen? [Segregation and inequality in Oslo school?]. In J. Ljunggren (Ed.), Oslo: Ulikhetenes by [Oslo: Unequal city] (pp. 257-276). Oslo: Cappelen Damm Akademisk.

Hanssen, G. S., \& Hofstad, H. (2013). Compact city policies in England, Denmark, the Netherlands and Norway. Oslo: Norwegian Institute for Urban Regional Research.

Haugen, C. R. (2020). Teachers' experiences of school choice from 'marginalised' and 'privileged' public schools in Oslo. Journal of Education Policy, 35(1), 68-94.

Hill, D. B. (2012). Gentrification in Oslo's Inner East: A spatial analysis, 1992 to 2008 (Master Thesis, Human Geography). University of Oslo, Department of Sociology and Human Geography, Oslo.

Hjorthol, R. J., \& Bjørnskau, T. (2005). Gentrification in Norway: Capital, culture or convenience? European Urban and Regional Studies, 12(4), 353-371. https:// doi.org/10.1177/0969776405058953

Huse, T. (2018). Gentrification and ethnicity. In L. Lees \& M. Phillips (Eds.), Handbook of gentrification studies. Cheltenham: Edward Elgar Publishing.

Imsen, G., Blossing, U., \& Moos, L. (2017). Reshaping the Nordic education model in an era of efficiency. Changes in the comprehensive school project in Denmark, Norway, and Sweden since the millennium. Scandinavian Journal of Educational Research, 61(5), 568-583.

Jacobs, J. (1961). The death and life of great American cities. New York: Random House.

Johannesen, K. L., Flatb $\varnothing$, Ø., Sellevold, A., \& Bohlin Borgersen, A. (2018). Startlånets utjevningsmuligheter [Start-up loan equalization options]. Oslo: Velferdsetaten, Oslo Kommune.

Karsten, L. (2003). Family gentrifiers: Challenging the city as a place simultaneously to build a career and to raise children. Urban Studies, 40(12), 2573-2584. https://doi.org/10.1080/0042098032000136228

Lilius, J. (2014). Is there room for families in the inner city? Life-stage blenders challenging planning. Housing Studies, 29(6), 843-861.

Lim, H. K., \& Kain, J.-H. (2016). Compact cities are complex, intense and diverse but: Can we design such emergent urban properties? Urban Planning, 1(1), 95-113.
Ludlow, D. (2006). Urban sprawl in Europe: The ignored challenge (No. 10/2006). Copenhagen: European Environment Agency. Retrieved from https:// www.eea.europa.eu/publications/eea_report_2006 10/eea_report_10_2006.pdf

Mete, S., \& Xue, J. (2020). Integrating environmental sustainability and social justice in housing development: Two contrasting scenarios. Progress in Planning. Advance online publication. https://doi.org/10.1016/ j.progress.2020.100504

Mikulyuk, A. B., \& Braddock, J. H. (2018). K-12 school diversity and social cohesion: Evidence in support of a compelling state interest. Education Urban Society, 50(1), 5-37.

Mouratidis, K. (2018). Is compact city livable? The impact of compact versus sprawled neighbourhoods on neighbourhood satisfaction. Urban Studies, 55(11), 2408-2430.

Næss, P., Næss, T., \& Strand, A. (2011). Oslo's farewell to urban sprawl. European Planning Studies, 19(1), 113-139.

Nordahl, B. (2020). Newbuilds and households in the market periphery: Norwegian housing and planning policy at a glance. In T. Moa (Ed.), Building affordable housing: Challanges and solutions in the Nordic Region (Vol. 2). Stockholm: Nordregio. Retrieved from https://nordregio.org/publications/buildingaffordable-homes-challenges-and-solutions-in-thenordic-region

OECD. (2012). Compact city policies: A comparative assessment. Paris: OECD.

Oslo Kommune. (1984). Oslo kommuneplan 1984 [Oslo municipal plan 1984]. Oslo: Oslo Kommune.

Oslo Kommune. (1991). Oslo kommuneplan 1991: Strategi for økonomisk handlefrihet, arealplan [Oslo Municipal Plan 1991: Strategy for economic freedom of action, area plan]. Oslo: Oslo Kommune.

Oslo Kommune. (2000). Kommuneplan 2000 [Municipal plan 2000]. Oslo: Oslo Kommune.

Oslo Kommune. (2008). Kommuneplan 2008. Oslo mot 2025 [Municipal Plan 2008. Oslo towards 2025] Oslo: Oslo Kommune.

Oslo Kommune. (2015a). Fortetting og transformasjon med bykvalitet $i$ bybåndet: Prosesser og virkemidler [Densification and transformation with urban quality in the urban area: Processes and tools]. Oslo: Oslo Kommune. Retrieved from https://www.regjeringen. no/contentassets/6679bd7b7bcf475eb947c3f2d54 e0029/fortetting_transformasjon_veileder_oa.pdf

Oslo Kommune. (2015b). Smart, trygg, grønn. Kommuneplan 2015. Oslo mot 2030. Samfunnsdel og byutviklingsstrategi [Smart, safe, green. Municipal plan 2015. Oslo towards 2030. Societal part and urban development strategy]. Oslo: Oslo Kommune.

Oslo Kommune. (2018). En grønnere, varmere og mer skapende by med plass til alle: Kommuneplan 2018 Samfunnsdel og byutviklingsstrategi [A greener, warmer and more creative city with room for every- 
one: Municipal plan 2018]. Oslo: Oslo Kommune.

Oslo Statistikkbanken. (2018a). Befolkningen etter landbakgrunn (G) [Population by country background]. Oslo: Oslo Statistikkbanken. Retrieved from http:// statistikkbanken.oslo.kommune.no/webview

Oslo Statistikkbanken. (2018b). Kvadratmeterpris og omsatte boliger [Price per square meter and sold homes]. Oslo: Oslo Statistikkbanken. Retrieved from http://statistikkbanken.oslo.kommune.no/webview

Oslo Statistikkbanken. (2018c). Rapport minoritetsspråk over tid 2013-2018 [Report minority languages over time 2013-2018]. Oslo: Oslo Statistikkbanken. Retrieved from http://statistikkbanken.oslo.kommune. no/webview

Oslo Statistikkbanken. (2018d). Boliger 2018. Delbydel [Housing 2018. Sub-district]. Oslo: Oslo Statistikkbanken. Retrieved from http://statistikkbanken. oslo.kommune.no/webview

Oslo Statistikkbanken. (2019). Boligmengden etter antall rom i boligen [Amount of housing according to number of rooms in the dwelling]. Oslo: Oslo Statistikkbanken. Retrieved from http://statistikkbanken. oslo.kommune.no/webview

Power, A. (2001). Social exclusion and urban sprawl: Is the rescue of cities possible? Regional Studies, 35(8), 731-742.

Quastel, N., Moos, M., \& Lynch, N. (2012). Sustainabilityas-density and the return of the social: The case of Vancouver, British Columbia. Urban Geography, 33(7), 1055-1084. https://doi.org/10.2747/02723638.33.7.1055

Rérat, P. (2012). Housing, the compact city and sustainable development: Some insights from recent urban trends in Switzerland. International Journal of Housing Policy, 12(2), 115-136.

Rice, J. L., Cohen, D. A., Long, J., \& Jurjevich, J. R. (2020). Contradictions of the climate-friendly city: New perspectives on eco-gentrification and housing justice. International Journal of Urban and Regional Research, 44(1), 145-165. https://doi.org/10.1111/ 1468-2427.12740

Rosol, M. (2015). Social mixing through densification?
The struggle over the Little Mountain public housing complex in Vancouver. Journal of the Geographical Society of Berlin, 146(2/3), 151-164.

Sandlie, H. C., \& Gulbrandsen, L. (2017). The social homeownership model-The case of Norway. Critical Housing Analysis, 4(1), 52-60.

Selvaag Bolig, OsloMet, \& Rodeo. (2019). Lærdom fra Løren: En tverrfaglig evaluering av utviklingen fra 2002 til 2019 [Learning from Løren: An interdisciplinary evaluation of the development from 2002 to 2019]. Oslo: Selvaag Bolig. Retrieved from https:// dokument.selvaagbolig.no/\#

Sharifi, A. (2016). From garden city to eco-urbanism: The quest for sustainable neighborhood development. Sustainable Cities and Society, 20, 1-16.

Ståhle, A. (2017). Closer together: This is the future of cities. Årsta: SCB Distributors.

Tammaru, T., Van Ham, M., Marcińczak, S., \& Musterd, S. (2015). Socio-economic segregation in European capital cities: East meets West. Abingdon: Routledge.

Turner, L. M., \& Wessel, T. (2013). Upwards, outwards and Westwards: Relocation of ethnic minority groups in the Oslo region. Geografiska Annaler: Series B, Human Geography, 95(1), 1-16. https://doi.org/ 10.1111/geob.12006

UN Habitat. (2014). Urban patterns for a green economy leveraging density. Nairobi: UNON Publishing Services.

Vowden, K. J. (2012). Safety in numbers? Middle-class parents and social mix in London primary schools. Journal of Education Policy, 27(6), 731-745.

Wessel, T. (2000). Social polarisation and socioeconomic segregation in a welfare state: The case of Oslo. Urban Studies, 37(11), 1947-1967.

Wessel, T., \& Lunke, E. B. (2019). Raising children in the inner city: Still a mismatch between housing and households? Housing Studies. https://doi.org/ 10.1080/02673037.2019.1686128

Wessel, T., \& Nordvik, V. (2019). Mixed neighbourhoods and native out-mobility in the Oslo region: The importance of parenthood. Urban Studies, 56(5), 885-905. https://doi.org/10.1177/0042098018768452

\section{About the Authors}

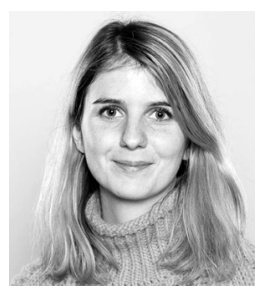

Rebecca Cavicchia is a PhD Candidate at the Department of Urban and Regional Planning at the Norwegian University of Life Sciences. Her background is in Architecture. Her research interests are social and spatial inequalities in green cities, urban sustainability policies, and housing justice.

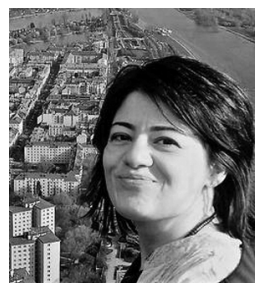

Roberta Cucca is an Associate Professor of Urban Sustainability Planning at the Norwegian University of Life Sciences (Department of Urban and Regional Planning). Her background is in Urban and Environmental Sociology. Previously, she was Marie Curie Fellow at the University of Vienna, Assistant Professor at the Polytechnic of Milan, Postdoctoral Fellow at the University of Toronto. Her main research interests are environmental policies and social vulnerability, social inequalities in contemporary cities, and participation in local policy decision making. 